\title{
Analisis Kepuasan Pelanggan terhadap Kualitas Pelayanan Jasa Ekspedisi dengan Metode Servqual dan Data Envelopment Analysis (DEA) di Kota Meulaboh
}

\author{
Arie Saputra ${ }^{1}$, Sofiyanurriyanti ${ }^{2}$ \\ ${ }^{1,2,3}$ Program Studi Teknik Industri, Fakultas Teknik, Universitas Teuku Umar, Meulaboh
}

\begin{abstract}
Assessment of service performance is important for the sustainability and existence of the company in the market. Objective performance measurement can be done to see the internal strength of the company and can also show how the company competes with companies that cover the same area. J\&T Express Meulaboh, which is a shipping service company in Meulaboh City, has never measured customer satisfaction, the management considers the services provided to be quite good, seen from visitors who use their services. An assessment of the company's performance has not been carried out so that it is not maintained whether it has used its resources efficiently and optimally. Measurement of company service performance is carried out using the Service Quality (Servqual) method to measure the level of customer satisfaction and the Data Envelopment Analysis (DEA) method to measure the company's efficiency value. The result of the 5 servqual gap calculation shows that all service quality attributes owned by J\&T Express Meulaboh are negative, which indicates that $J \& T$ Express service performance has not met the expectations of customers who use its services. The results of calculations using the DEA method show that J\&T Express Meulaboh is quite good and efficient with an efficient value of 1 .
\end{abstract}

Keyword: Service Quality, Customer Satisfaction, Performance, Gap, Efficiency

Abstrak. Penilaian mengenai kinerja pelayanan penting dilakukan demi keberlangsungan dan eksistensi perusahaan dipasaran. Pengukuran kinerja secara objektif dapat dilakukan untuk mengetahui kekuatan internal yang dimiliki perusahaan dan juga dapat menunjukkan bagaimana perusahaan berkompetisi dengan perusahaan sejenis dalam lingkup wilayah yang sama. $J \& T$ Express Meulaboh yang merupakan perusahaan jasa pengiriman barang di Kota Meulaboh belum pernah melakukan pengukuran kepuasan pelanggan, pihak manajemen menganggap pelayanan yang diberikan telah cukup baik dilihat dari pengunjung yang menggunakan jasanya. Penilaian terhadap kinerja perusahaan juga belum dilakukan sehingga perusahaan tidak mengetahui apakah telah menggunakan sumber daya yang dimiliki dengan efisien dan optimal. Pengukuran kinerja pelayanan perusahaan dilakukan dengan menggunakan metode Service Quality (Servqual) untuk mengetahui tingkat kepuasan pelangaan dan metode Data Envelopment Analysis (DEA) untuk mengetahui nilai efisiensi perusahaan. Hasil perhitungan gap 5 servqual menunjukkan bahwa seluruh atribut kualitas pelayanan yang dimiliki oleh J\&T Express Meulaboh bernilai negatif, yang menunjukkan bahwa kinerja pelayanan J\&T Express belum memenuhi ekspektasi pelanggan yang menggunakan jasanya. Hasil pehitungan dengan menggunakan metode DEA menunjukkan

${ }^{*}$ Corresponding author at: Universitas Teuku Umar, Meulaboh 
bahwa J\&T Express Meulaboh telah beroperasi cukup baik dan efisien dengan mendapat nilai efisiensi relatif sebesar 1

Kata Kunci: Kualitas Pelayanan, Kepuasan Pelanggan, Kinerja, Gap, Efisiens

Received 22 October 2020 | Revised 26 December 2020 | Accepted 25 January 2021

\section{Pendahuluan}

Kualitas pelayanan sangat berpengaruh terhadap kepuasan pelanggan. Peningkatan kualitas pelayanan berbanding positif terhadap peningkatan kepuasan pelanggan terhadap sebuah produk atau jasa [1].

Kualitas pelayanan dalam industri jasa adalah salah satu unsur penting untuk diperhatikan. Hal ini disebabkan oleh kualitas pelayanan merupakan salah satu alat yang digunakan untuk mengukur kinerja organisasi[2]. Kualitas jasa adalah tingkat keunggulan yang diharapkan dan pengendalian atas tingkat keunggulan tersebut untuk memenuhi keinginan pelanggan [3].

Kinerja perusahaan dalam memberikan pelayanan yang baik terhadap konsumen akan menggambarkan kemampuan perusahaan bersaing dengan perusahaan lain yang sejenis pada suatu daerah yang sama. Pengukuran kinerja dapat secara objektif membandingkan kemampuan organisasi tidak berdasarkan kekuatan internal yang dimiliki saja, tetapi menunjukkan bagaimana perusahaan berkompetisi secara eksternal dengan perusahaan sejenis lainnya. Penilaian atribut kinerja dapat disesuaikan dengan atribut pelayanan jasa, sehingga penilaian terhadap kinerja juga akan melihat kualitas pelayanan yang dimiliki oleh perusahaan.

J\&T Express adalah Salah satu perusahaan ekspedisi yang ada di kota Meulaboh. Perusahaan ini sudah beroperasi selama empat tahun dikota Meulaboh, dengan kantor cabang terletak di Jln, Teuku Umar Meulaboh, Kabupaten Aceh Barat. Dalam kegiatan pelayanan yang dilakukan pihak perusahaan berupaya untuk dapat memberikan pelayanan yang optimal. Tetapi, berdasarkan observasi awal yang telah dilakukan terhadap beberapa pelanggan yang pernah menggunakan jasa ekspedisi J\&T Express Meulaboh, mengungkapkan bahwa masih terdapat beberapa hal yang membuat pelanggan merasa tidak puas dengan layanan yang ditawarkan. Beberapa diantaranya adalah paket kiriman tidak sampai ditujuan sesuai dengan waktu yang dijanjikan, adanya kerusakan pada produk saat pengiriman, juga beberapa petugas tidak mampu memahami pelayanan yang ditawarkan. Dilain sisi pihak J\&T Express Meulaboh belum pernah melakukan tingkat pengukuran kepuasan pelanggan. Pihak J\&T Express beranggapan bahwa pelayanan yang diberikan sudah cukup baik dikarenakan pengunjung yang menggunakan jasanya telah cukup banyak. Selain itu juga, J\&T Express Meulaboh juga belum melakukan penilaian terhadap kinerja yang dilakukannya selama perusahaan beroperasi, sehingga perusahaan tidak mengetahui apakah sudah menggunakan sumber daya yang dimiliki dengan efisien dan optimal.

Penelitian terkait kepuasan pelanggan seringkali diselidiki secara parsial dari sisi kinerja internal perusahaan. Salah satunya melalui service quality dan kebijakan security perusahaan [4]. Sebaliknya kinerja perusahaan secara global dengan mebandingkan dengan perusahaan lain [5] 
juga seharusnya membutuhkan penyelidikan lebih mendalam dengan melihat kemapuan perusahaan dari sisi internalnya.

Penelitian ini bertujuan untuk menentukan seberapa besar tingkat kepuasan pelanggan dengan melihat kinerja perusahaan dari sisi internal berdasarkan perspektif pelanggan. Kinerja secara internal ini akan diukur melalui metode servqual. Kinierja internal ini kemudian akan dibandingkan lagi dengan kemampuan perusahaan berkompetisi (kinerja eksternal) dengan perusahaan lain melalui metode Data Envelopment Analisys (DEA). Melalui metode Servqual akan diselidiki kualitas layanan dari atribut masing-masing dimensi, sehingga akan diperoleh nilai gap (kesenjangan) yang merupakan selisih antara persepsi konsumen terhadap layanan yang telah diterima dengan harapan terhadap yang akan diterima[6]. Persepektif konsumen akan diuji secara lebih lanjut melaui metode DEA untuk mendapatkan gambaran yang jelas mengenai posisi kinerja perusahaan dalam hal ini J\&T Express dengan perusahaan ekspedisi lainnya. Dalam dunia usaha DEA diaplikasikan dalam untuk mengukur efisiensi relatif kinerja pada unit organisasi yang disebut unit pengambilan keputusan (DMU) [7].

\section{Metodologi Penelitian}

Penelitian ini dilakukan di J\&T Express Meulaboh yang bergerak dalam bidang jasa logistik dan pengiriman barang lingkup kota, domestik hingga mancanegara. Salah satu cabang dari perusahaan ini beralamat di JL. Teuku Umar, Desa Ujung Kalak, Kota Meulaboh, Aceh Barat. Waktu pelaksanaan penelitian dilakukan selama delapan bulan dimulai dari bulan November 2019 hingga Juni 2020. Penelitian ini dilakukan di J\&T Express Meulaboh yang bergerak dalam bidang jasa logistik dan pengiriman barang lingkup kota, domestik hingga mancanegara.

Rancangan Penelitian dapat dilihat pada blok diagram metodologi penelitian dapat dilihat pada Gambar 1 berikut: 


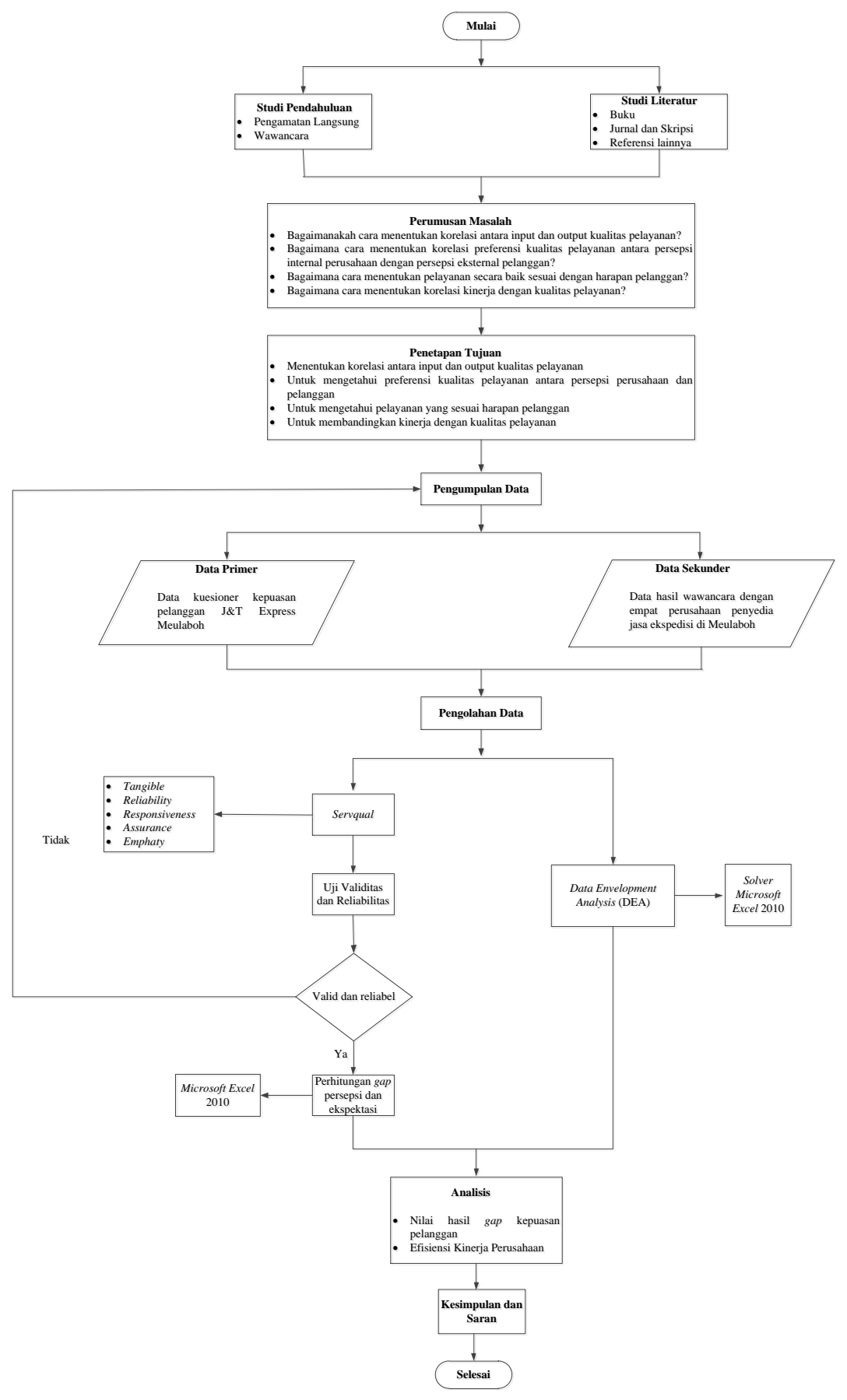

Gambar 1 Blok Diagram Prosedur Penelitian

Jumlah populasi pengunjung J\&T Express Meulaboh pada penelitian ini tidak dapat diketahui dengan pasti, sehingga untuk menentukan jumlah sampel dilakukan secara acak dengan menggunakan rumus Rao Purba [8] berikut:

$$
\mathrm{n}=\frac{\mathrm{z}^{2}}{4(\mathrm{Moe})^{2}}
$$

\section{Keterangan:}

$$
\begin{array}{ll}
\mathrm{n} & =\text { Ukuran sampel } \\
\mathrm{z} & =\text { Tingkat keyakinan yang dalam penentuan sampel } 95 \%=1,96
\end{array}
$$


Moe $\quad=$ Margin of error atau kesalahan maksimal yang bisa ditoleransi

Maka dengan menggunakan rumus diatas, jumlah sampel minimal adalah sebagai berikut:

$$
\mathrm{n}=\frac{1.96^{2}}{4(0.10)^{2}}=\frac{1.96^{2}}{0.04}=96,04 \approx 97 \text { orang sampel }
$$

Setelah perhitungan, maka ditentukan jumlah sampel minimal penelitian adalah sebanyak 97 orang sampel.

\section{Hasil dan Pembahasan}

\subsection{Pengumpulan Data}

Data yang dikumpulkan pada penelitian ini merupakan data survey pelanggan J\&T Express Meulaboh dan wawancara dengan pihak manajemen perusahaan ekspedisi. Data hasil survey kepuasan pelanggan dapat dilihat pada link https://bit.ly/34KfwJe. Data hasil wawancara dengan pihak manajemen empat perusahaan yaitu terlihat pada Tabel 1 berikut:

Tabel 1 Rekapitulasi Data Wawancara Masing-Masing DMU

\begin{tabular}{ccccccccccc}
\hline \multirow{2}{*}{ DMU } & \multicolumn{2}{c}{ Output } & \multicolumn{1}{c}{ Input } \\
\cline { 2 - 10 } & Pengunjung & Pendapatan & $\begin{array}{c}\text { Lama } \\
\text { Beroperasi }\end{array}$ & $\begin{array}{c}\text { Banyak } \\
\text { Cabang }\end{array}$ & Fitur & $\begin{array}{c}\text { Akses } \\
\text { Media }\end{array}$ & Jaminan & $\begin{array}{c}\text { Modal } \\
\text { Awal }\end{array}$ & $\begin{array}{c}\text { Karyawan } \\
\text { Training } \\
\text { karyawan }\end{array}$ \\
\hline 1 & 3000 & 90.000 .000 & 4 & 3000 & 4 & 2 & 1 & 50.000 .000 & 14 & 1 \\
2 & 450 & 70.000 .000 & 8 & 512 & 3 & 2 & 1 & 100.000 .000 & 7 & 1 \\
3 & 300 & 20.000 .000 & 17 & 450 & 2 & 2 & 1 & 100.000 .000 & 5 & 0 \\
4 & 1000 & 50.000 .000 & 19 & 4800 & 5 & 2 & 1 & 75.000 .000 & 20 & 1 \\
\hline
\end{tabular}

\subsection{Pengolahan Data}

\section{A. Hasil Pengujian Validitas dan Reliabilitas Kuesioner}

Pengujian alat ukur yang dilakukan dalam penelitian ini adalah dengan menggunakan uji validitas dan reliabilitas. Pengujian dilakukan untuk membuktikan akurasi dan kehandalan dari kuesioner sebagai instrumen penelitian.

Pengujian signifikansi dilakukan dengan membandingkan nilai $\mathbf{r}_{\text {hitung }}$ dengan $\mathbf{r}_{\text {tabel }}$ yang ada di tabel r statistik dengan uji dua arah. Dasar pengambilan keputusannya adalah jika $r_{\text {hitung }}>r_{\text {tabel }}$ dan bernilai positif, maka variabel tersebut valid. Sedangkan, jika $\mathrm{r}_{\text {hitung }}<\mathrm{r}_{\text {tabel }}$ maka variabel tersebut dikatakan tidak valid [9]. Uji validitas instrumen dapat menggunakan rumus korelasi, Rumus korelasi berdasarkan Pearson Product Moment adalah sebagai berikut:

$$
r_{x y}=\frac{n \sum X Y-\sum X \sum Y}{\sqrt{\left(n \sum X^{2}-\left(\sum X\right)^{2}\right)\left(n \sum Y^{2}-\left(\sum Y\right)^{2}\right)}}
$$

Keterangan:

rxy $=$ Koefisien Korelasi variabel $\mathrm{x}$ dan variabel $\mathrm{y}$ 
$\mathrm{x}=$ Nilai data ke-i untuk kelompok variabel $\mathrm{x}$

$\mathrm{y} \quad=$ nilai data ke-i untuk kelompok variabel $\mathrm{y}$

$\mathrm{n} \quad=$ Banyaknya data

Uji validitas dilakukan terhadap delapan belas butir pertayaan dalam kuesioner, dengan jumlah responden sebanyak 97 orang dan nilai $\alpha=5 \%$ dengan nilai sebesar 0,198 pada $r$ Tabel. Perhitungan manual butir pertanyaan P1 kuesioner persepsi pelanggan dengan menggunakan rumus diatas adalah sebagai berikut:

$$
\begin{aligned}
& \mathrm{r}_{\mathrm{xy}}=\frac{(97 \times 28802)-(401 \times 6915)}{\sqrt{\left((97 \times 1695)-\left((401)^{2}\right) \times\left((97 \times 496951)-(6915)^{2}\right)\right)}} \\
& \mathrm{r}_{\mathrm{xy}}=\frac{2793794-2772915}{\sqrt{((164415-160801) \times(48204247-47817225))}} \\
& \mathrm{r}_{\mathrm{xy}}=\frac{20879}{\sqrt{(3614 \times 387022)}}=\frac{20879}{\sqrt{13986975508}}=\frac{20879}{37399,2}=0,558
\end{aligned}
$$

Hasil perhitungan uji validitas untuk seluruh kuesioner persepsi pelanggan dapat dilihat pada Tabel 2.

Tabel 2 Rekapitulasi Pengujian Validitas Kuesioner Persepsi Pelanggan

\begin{tabular}{cccc}
\hline Pertanyaan ke- & r-hitung & r- tabel & Kesimpulan \\
\hline $\mathrm{P}_{1}$ & 0,558 & 0,198 & Valid \\
$\mathrm{P}_{2}$ & 0,392 & 0,198 & Valid \\
$\mathrm{P}_{3}$ & 0,606 & 0,198 & Valid \\
$\mathrm{P}_{4}$ & 0,630 & 0,198 & Valid \\
$\mathrm{P}_{5}$ & 0,520 & 0,198 & Valid \\
$\mathrm{P}_{6}$ & 0,704 & 0,198 & Valid \\
$\mathrm{P}_{7}$ & 0,642 & 0,198 & Valid \\
$\mathrm{P}_{8}$ & 0,577 & 0,198 & Valid \\
$\mathrm{P}_{9}$ & 0,549 & 0,198 & Valid \\
$\mathrm{P}_{10}$ & 0,393 & 0,198 & Valid \\
$\mathrm{P}_{11}$ & 0,600 & 0,198 & Valid \\
$\mathrm{P}_{12}$ & 0,484 & 0,198 & Valid \\
$\mathrm{P}_{13}$ & 0,497 & 0,198 & Valid \\
$\mathrm{P}_{14}$ & 0,283 & 0,198 & Valid \\
$\mathrm{P}_{15}$ & 0,318 & 0,198 & Valid \\
$\mathrm{P}_{16}$ & 0,528 & 0,198 & Valid \\
$\mathrm{P}_{17}$ & 0,462 & 0,198 & Valid \\
$\mathrm{P}_{18}$ & 0,426 & 0,198 & Valid \\
\hline
\end{tabular}

Serta kuesioner ekspektasi pelanggan seperti terlihat Tabel 3 berikut. 
Tabel 3 Rekapitulasi Pengujian Validitas Kuesioner Ekspektasi Pelanggan

\begin{tabular}{cccc}
\hline Pertanyaan ke- & r-hitung & r- tabel & Kesimpulan \\
\hline $\mathrm{P}_{1}$ & 0,659 & 0,198 & Valid \\
$\mathrm{P}_{2}$ & 0,618 & 0,198 & Valid \\
$\mathrm{P}_{3}$ & 0,693 & 0,198 & Valid \\
$\mathrm{P}_{4}$ & 0,750 & 0,198 & Valid \\
$\mathrm{P}_{5}$ & 0,657 & 0,198 & Valid \\
$\mathrm{P}_{6}$ & 0,763 & 0,198 & Valid \\
$\mathrm{P}_{7}$ & 0,761 & 0,198 & Valid \\
$\mathrm{P}_{8}$ & 0,832 & 0,198 & Valid \\
$\mathrm{P}_{9}$ & 0,715 & 0,198 & Valid \\
$\mathrm{P}_{10}$ & 0,800 & 0,198 & Valid \\
$\mathrm{P}_{11}$ & 0,734 & 0,198 & Valid \\
$\mathrm{P}_{12}$ & 0,578 & 0,198 & Valid \\
$\mathrm{P}_{13}$ & 0,588 & 0,198 & Valid \\
$\mathrm{P}_{14}$ & 0,678 & 0,198 & Valid \\
$\mathrm{P}_{15}$ & 0,565 & 0,198 & Valid \\
$\mathrm{P}_{16}$ & 0,586 & 0,198 & Valid \\
$\mathrm{P}_{17}$ & 0,437 & 0,198 & Valid \\
$\mathrm{P}_{18}$ & 0,732 & 0,198 & Valid \\
\hline
\end{tabular}

Tabel 2 dan Tabel 3 menunjukkan hasil perhitungan uji validitas pada kuesioner persepsi dan kuesioner ekspektasi pelanggan. Seluruh atribut memiliki hasil yang valid, hal ini dikarenakan setiap angka $r$ hitung $>r$ tabel.

Pengukuran kehadnalan kuesioner dilakukan denan menggunakan uji raliabilitas. Hasil ukur dapat dipercaya apabila dalam beberapa kali pengukuran terhadap kelompok subjek yang sama diperoleh hasil yang relatif sama[10]. Pengujian reliabilitas kuesioner dilakukan menggunakan persamaan rumus reliabilitas Alpha Cronbach yaitu sebagai berikut:

$$
\mathrm{r}_{11}=\left[\frac{\mathrm{K}}{\mathrm{K}-1}\right]\left[1-\frac{\sum \sigma \mathrm{b}^{2}}{\sigma_{\mathrm{t}}{ }^{2}}\right]
$$

Keterangan:

$r_{11}=$ Reliabilitas Instrumen

$\mathrm{K}=$ Banyak butir pertanyaan

$\sigma_{t}^{2} \quad=$ Varian total

$\sum \sigma b^{2}=$ Jumlah varian butir

Perhitungan reliabilitas dilakukan pada kuesioner persepsi dan ekspektasi pelanggan. Berikut contoh perhitungan manual reliabilitas pada kuesioner persepsi pelanggan.

$$
\begin{aligned}
& r_{11}=\left[\frac{18}{18-1}\right]\left[1-\frac{8,941}{41,562}\right] \\
& r_{11}=[1,059][0,785]=0,831
\end{aligned}
$$

Hasil perhitungan uji reliabilitas untuk seluruh kuesioner persepsi pelanggan dan kuesioner ekspektasi pelanggan seperti terlihat pada Tabel 4 berikut: 
Tabel 4 Rekapitulasi Pengujian Realiabilitas Butir Kuesioner

\begin{tabular}{clcc}
\hline No & \multicolumn{1}{c}{ Variabel } & Nilai Alpha Cronbach & Kesimpulan \\
\hline 1 & Kuesioner Persepsi Pelanggan & 0,831 & Reliable \\
2 & Kuesioner Ekspektasi Pelanggan & 0,926 & Reliable \\
\hline
\end{tabular}

Hasil dari pengujian reliabilitas pada Tabel 4 menunjukkan bahwa, nilai setiap variabel menunjukkan nilai yang konsisten dan dapat dipercaya kebenaran datanya. Hal ini dikarenakan setiap variabel kuesioner memiliki nilai lebih besar dari 0,6 yaitu dengan nilai 0,831 untuk variabel kuesioner persepsi pelanggan dan dengan nilai 0,926 untuk variabel kuesioner ekspekatasi pelanggan.

\section{B. Perhitungan Gap 5 Persepsi dan Ekspektasi Pelanggan}

Perhitungan Gap 5 dilakukan dengan penerapan prinsip item-by-item analysis [11]. Uraian perhitungan Gap 5 Servqual secara manual adalah sebagai berikut:

Gap $5 \mathrm{P}_{1}=$ Rata-Rata Nilai Persepsi $\mathrm{P}_{1}-$ Rata-Rata Nilai Ekspektasi $\mathrm{P}_{1}$

Gap $5 \mathrm{P}_{1}=\left(\frac{5+5+4+4+4+3+\ldots+5+4}{97}\right)-\left(\frac{5+5+4+3+3+5+\ldots+5+5}{97}\right)=\left(\frac{401}{97}\right)-\left(\frac{431}{97}\right)$

Gap $5 \mathrm{P}_{1}=4,13-4,44=-0,31$

Hasil perhitungan gap 5 secara keseluruhan untuk atribut berikutnya secara berurut dapat dilihat pada Tabel 5 berikut.

Tabel 5 Rekapitulasi Hasil Perhitungan Gap 5 Servqual

\begin{tabular}{|c|c|c|c|c|c|c|c|}
\hline \multirow[b]{2}{*}{$\begin{array}{l}\text { No } \\
\text { Item }\end{array}$} & \multicolumn{2}{|c|}{ Rata-rata per item } & \multirow[b]{2}{*}{$P-E$} & \multirow[b]{2}{*}{ Dimensi } & \multicolumn{2}{|c|}{ Rata-rata Per Dimensi } & \multirow[b]{2}{*}{$\begin{array}{c}\text { Skor } \\
\text { Servqual }\end{array}$} \\
\hline & $\begin{array}{l}\text { Persepsi } \\
\text { (P) }\end{array}$ & $\begin{array}{l}\text { Ekspektasi } \\
\text { (E) }\end{array}$ & & & $\begin{array}{l}\text { Persepsi } \\
\text { (P) }\end{array}$ & $\begin{array}{l}\text { Ekspektasi } \\
\text { (E) }\end{array}$ & \\
\hline $\mathrm{P}_{1}$ & 4,13 & 4,44 & $-0,31$ & \multirow{3}{*}{$\begin{array}{r}\text { Kehandalan } \\
\text { (Item } 1 \text { - 3) }\end{array}$} & \multirow{3}{*}{4,14} & \multirow{3}{*}{4,52} & \multirow{3}{*}{$-0,38$} \\
\hline $\mathrm{P}_{2}$ & 4,22 & 4,55 & $-0,33$ & & & & \\
\hline $\mathrm{P}_{3}$ & 4,07 & 4,58 & $-0,51$ & & & & \\
\hline $\mathrm{P}_{4}$ & 4,03 & 4,56 & $-0,53$ & Daya & \multirow{3}{*}{4,05} & \multirow{3}{*}{4,58} & \multirow{3}{*}{$-0,53$} \\
\hline $\mathrm{P}_{5}$ & 4,10 & 4,55 & $-0,44$ & Tanggap & & & \\
\hline $\mathrm{P}_{6}$ & 4,01 & 4,64 & $-0,63$ & (Item $4-6)$ & & & \\
\hline $\mathrm{P}_{7}$ & 3,84 & 4,59 & $-0,75$ & \multirow{3}{*}{$\begin{array}{l}\text { Jaminan } \\
\text { (Item } 7 \text { - 9) }\end{array}$} & \multirow{3}{*}{3,96} & \multirow{3}{*}{4,60} & \multirow{3}{*}{$-0,63$} \\
\hline $\mathrm{P}_{8}$ & 3,95 & 4,63 & $-0,68$ & & & & \\
\hline $\mathrm{P}_{9}$ & 4,10 & 4,57 & $-0,46$ & & & & \\
\hline $\mathrm{P}_{10}$ & 4,49 & 4,71 & $-0,22$ & $\begin{array}{c}\text { Empati (item } \\
10-11)\end{array}$ & 4,26 & 4,66 & $-0,40$ \\
\hline $\mathrm{P}_{11}$ & 4,02 & 4,60 & $-0,58$ & \multirow{8}{*}{$\begin{array}{c}\text { Bukti Fisik } \\
\text { (Item 12-18) }\end{array}$} & \multirow{8}{*}{3,76} & \multirow{8}{*}{4,44} & \multirow{8}{*}{$-0,68$} \\
\hline $\mathrm{P}_{12}$ & 4,05 & 4,41 & $-0,36$ & & & & \\
\hline $\mathrm{P}_{13}$ & 3,64 & 4,37 & $-0,73$ & & & & \\
\hline $\mathrm{P}_{14}$ & 4,13 & 4,44 & $-0,31$ & & & & \\
\hline $\mathrm{P}_{15}$ & 4,22 & 4,55 & $-0,33$ & & & & \\
\hline $\mathrm{P}_{16}$ & 4,07 & 4,58 & $-0,51$ & & & & \\
\hline $\mathrm{P}_{17}$ & 3,81 & 4,34 & $-0,53$ & & & & \\
\hline $\mathrm{P}_{18}$ & 4,26 & 4,71 & $-0,45$ & & & & \\
\hline
\end{tabular}


Hasil perhitungan gap 5 servqual menunjukkan bahwa seluruh atribut kualitas pelayanan yang dimiliki oleh $J \& T$ Express Meulaboh bernilai negatif. Maknanya semakin negatif nilai yang dihasilkan, maka akan semakin jauh dari harapan yang dinginkan oleh pelanggan. Hal ini dapat disimpulkan bahwa kinerja pelayanan J\&T Express belum memenuhi ekspektasi pelanggan yang menggunakan jasanya.

\section{Perhitungan Data Metode Data Envelopment Analysis (DEA)}

Dalam pembahasan ini akan diukur efisiensi kinerja dari J\&T Express Meulaboh dengan tiga perusahaan sejenis yang menjadi pesaing di Kota Meulaboh dengan menggunakan metode DEA. Untuk mempermudah langkah dalam melakukan pengolahan data, maka peneliti mengelompokkan masing-masing perusahaan ke dalam bentuk Decision Making Unit (DMU). Berikut keterangan masing-masing DMU dalam penelitian ini:

1. J\&T Express Meulaboh (DMU1)

2. Indah Cargo Meulaboh (DMU2)

3. TIKI Meulaboh (DMU3)

\section{PT Pos Indonesia (DMU4)}

Pengolahan data DEA, memerlukan data mengenai atribut kinerja yang dimiliki masing-masing perusahaan, yaitu melalui variabel input dan output. Penentuan variabel input didasarkan pada aturan DEA yang mengharuskan bahwa variabel input harus sesuatu yang diperlukan oleh satu unit organisasi untuk menghasilkan output. Selanjutnya penentuan varaiabel output harus sesuatu yang dihasilkan dari serangkaian input yang dipakai oleh suatu unit usaha. Atribut input dan output yang didapat dari proses wawancara, direkapitulasi seperti terlihat pada Tabel 1 diatas selanjutnya di selesaikan menggunakan program Solver pada Microsoft Excel 2010. Langkah Pengerjaannya adalah sebagai berikut:

1. Data hasil wawancara dimasukkan ke dalam lembar kerja Microsoft Excel

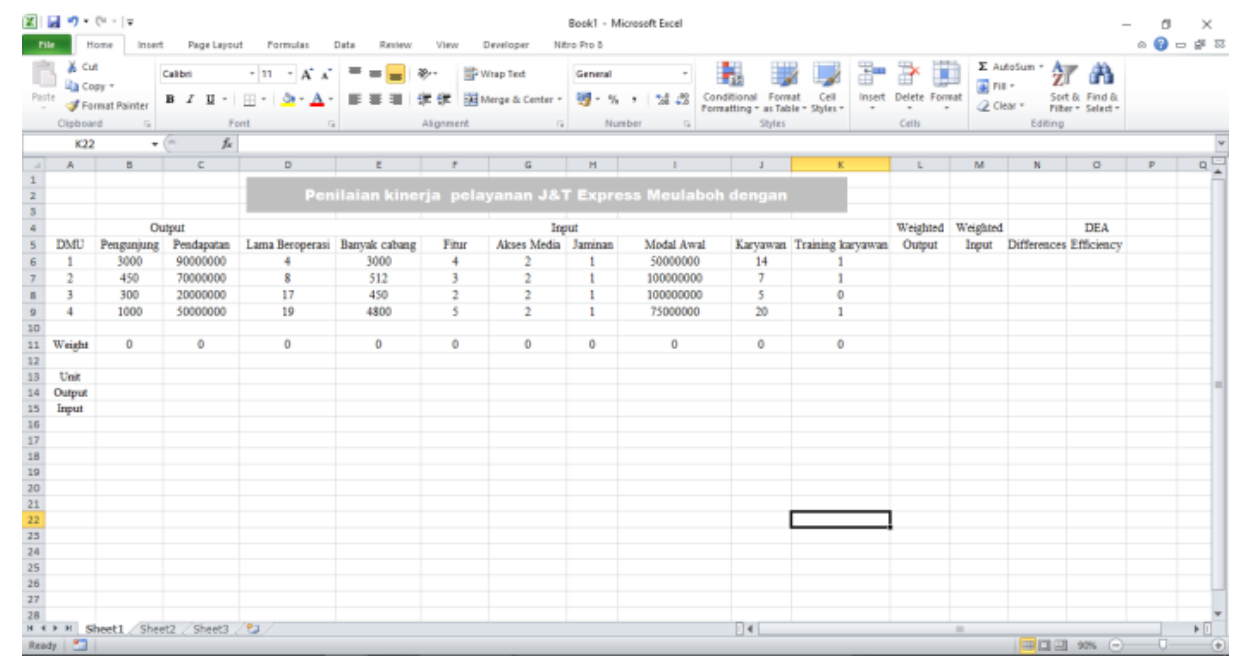

Gambar 1 Tampilan Data yang telah di-input ke Microsoft Excel 
2. Selanjutnya memberikan fungsi rumus pada kolom weighted output dan dengan rumus SUMPRODUCT, lalu seret ke bawah sebanyak DMU yang akan dinilai. Gunakan rumus dan langkah yang sama pada kolom weighted input.

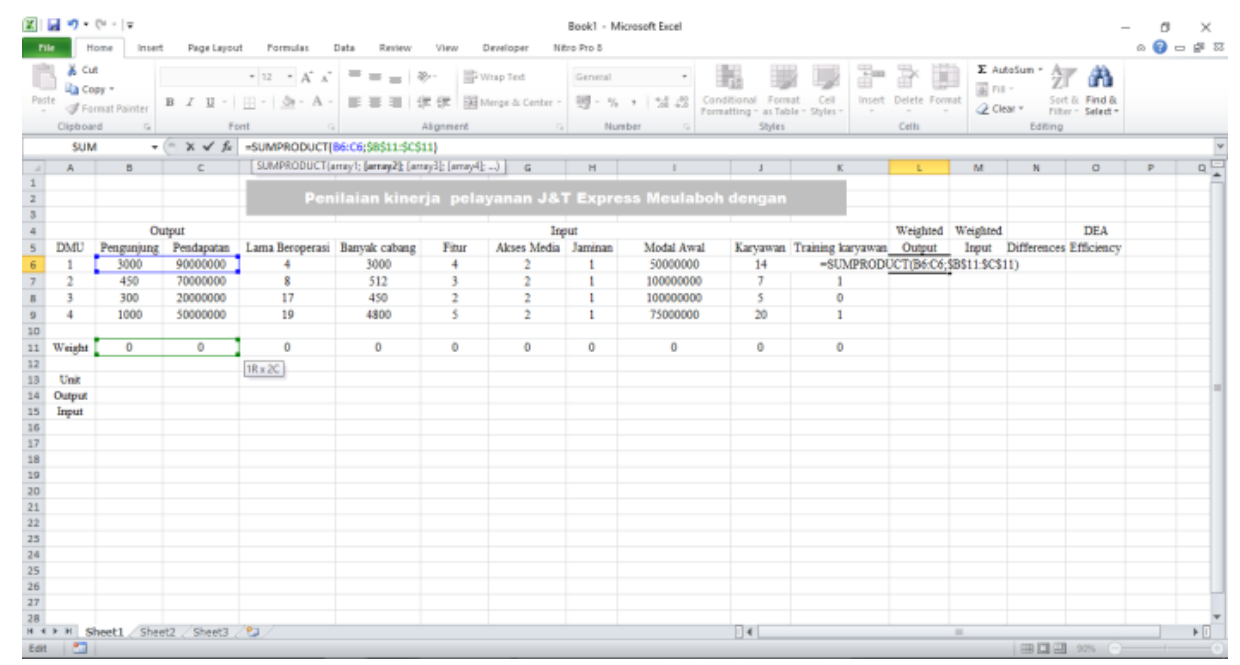

Gambar 2 Tampilan Fungsi Rumus Pembobotan Input

3. Langkah berikutnya adalah memberikan fungsi rumus pada baris output dan input dengan menggunakan fungsi INDEX.

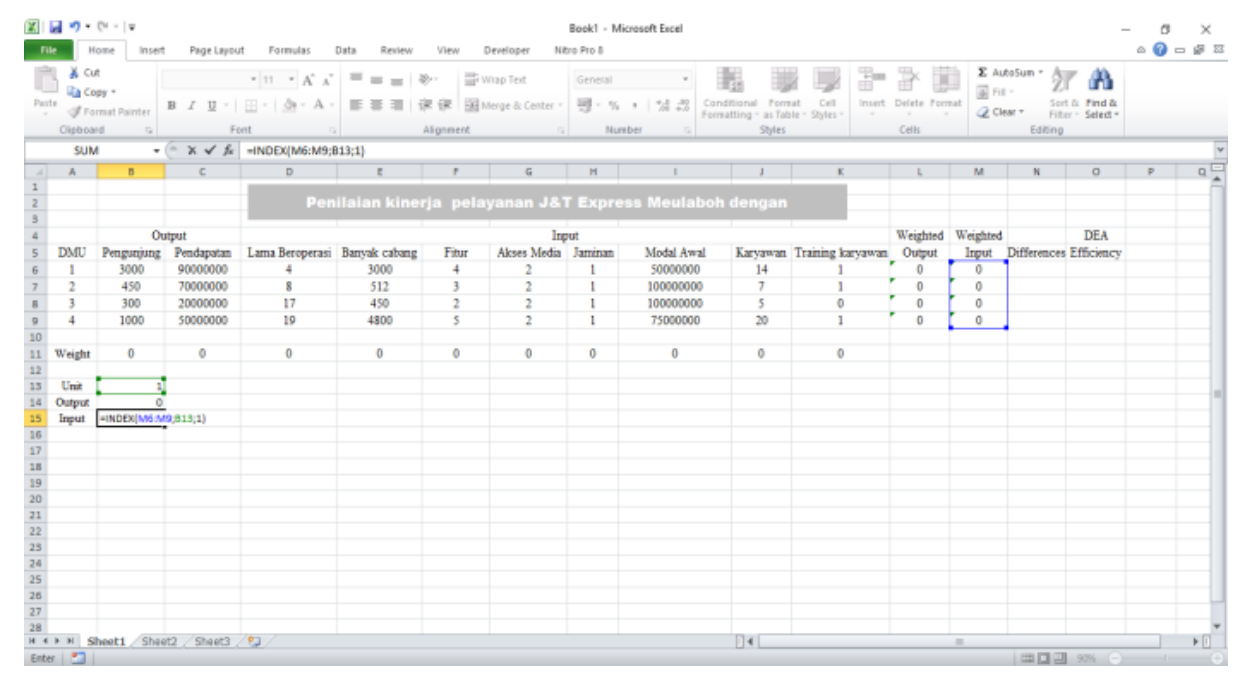

Gambar 3 Tampilan Fungsi Rumus Output

4. Berikutnya memberikan fungsi rumus pada kolom differences dengan mengurangkan setiap baris pada kolom weighted output dengan kolom weighted input. Lalu seret kebawah sebanyak DMU yang akan dinilai. 


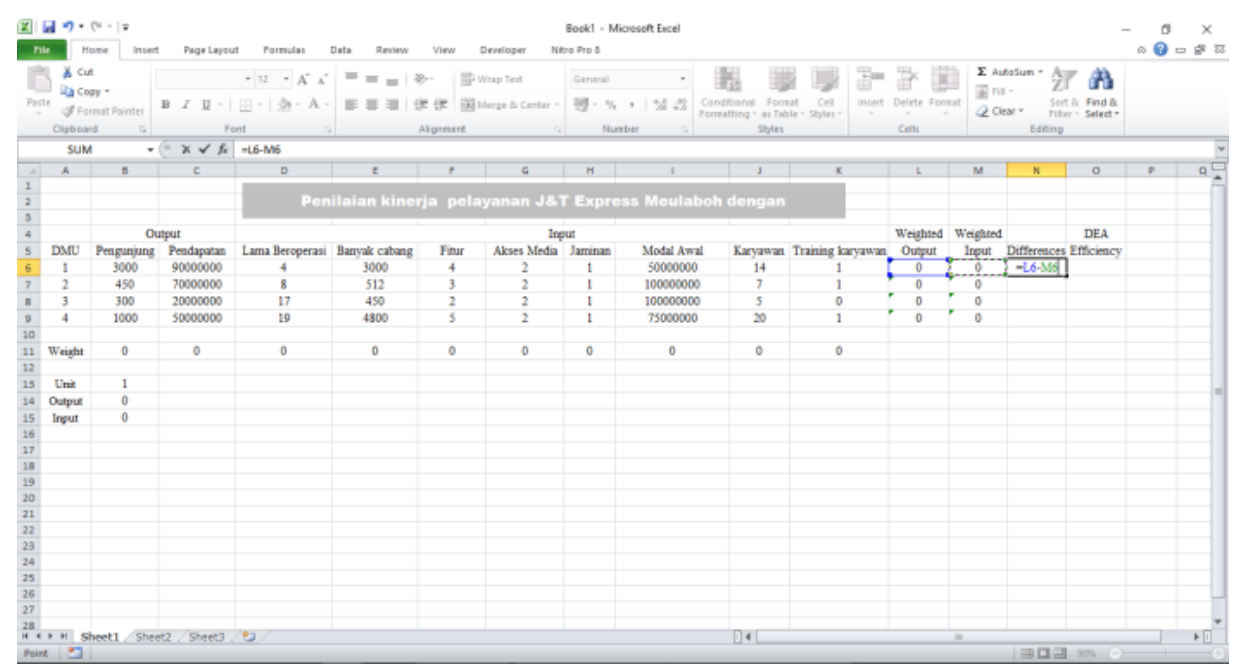

Gambar 4 Tampilan Fungsi Rumus Kolom Differences

5. Langkah selanjutnya adalah mengaktifkan menu solver, dan atur fungsi tujuan, variabel, dan batasannya

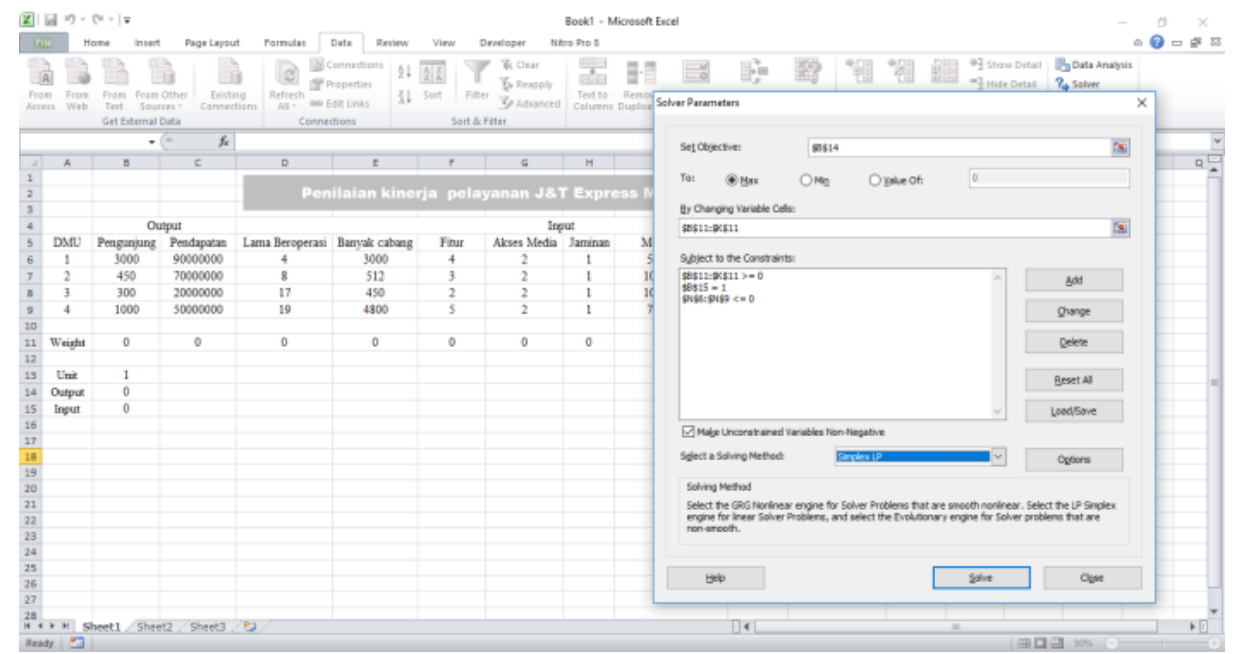

Gambar 5 Tampilan Solver Parameter

6. Setelah selesai mengatur maka akan muncul hasil solver yaitu nilai bobot setiap input dan output. 


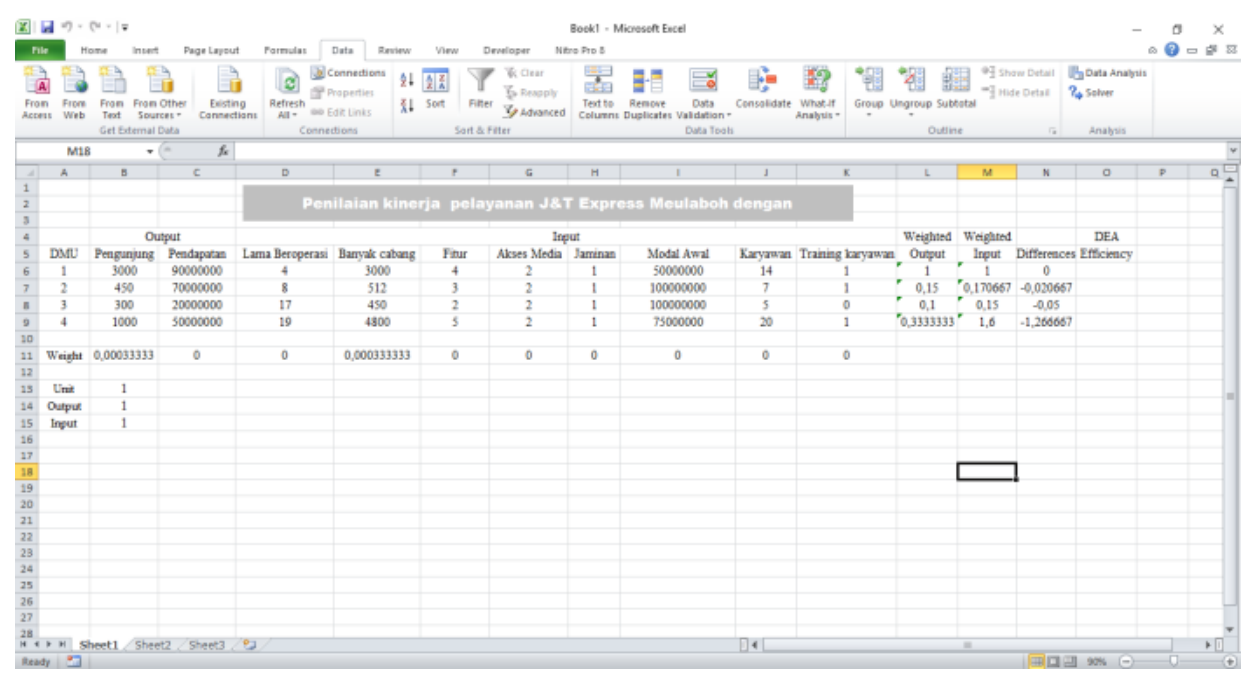

Gambar 6 Tampilan Hasil Solver Parameter

7. Kemudian aktifkan command button untuk menjalankan Run DEA dengan cara memilih menu Developer > insert > Command Button (pada bagian ActiveX Controls) lalu seret ke lembar kerja.

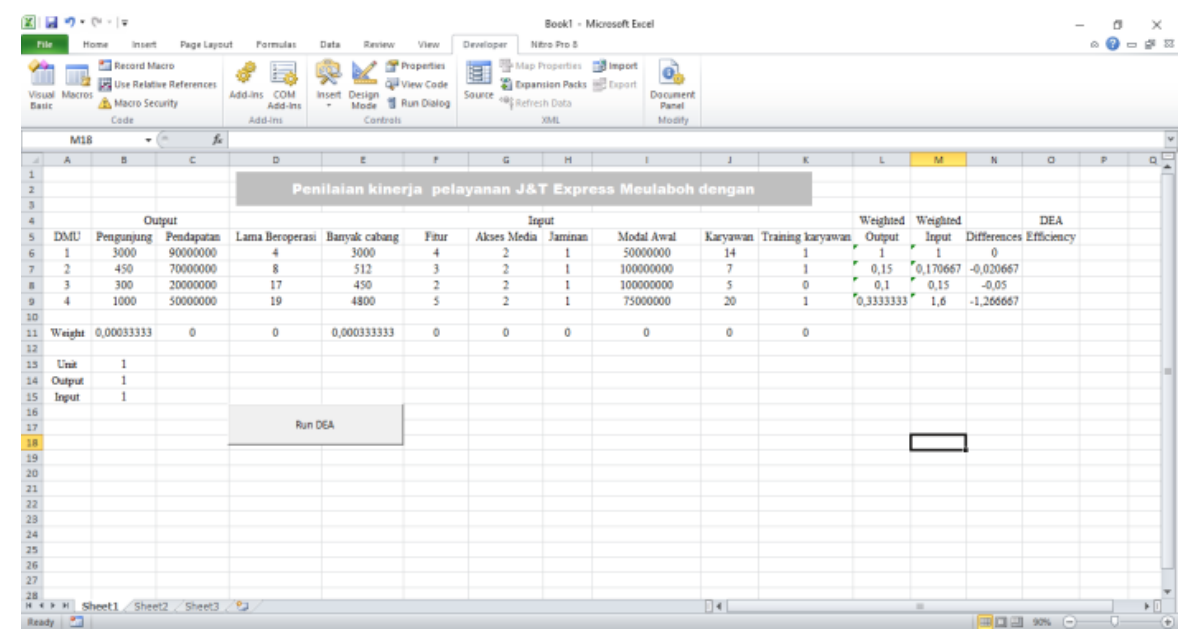

Gambar 7 Tampilan Hasil Aktivasi Command Button

8. Selanjutnya adalah memprogram dengan menggunakan visual basic.untuk masuk klik dua kali pada kotak command button 


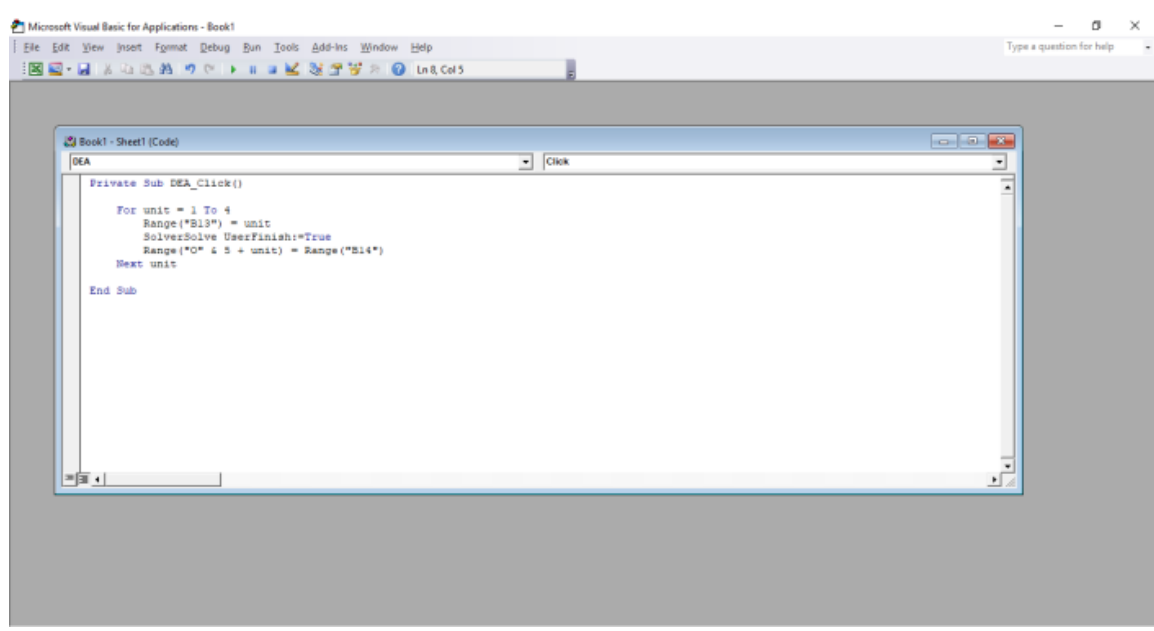

Gambar 8 Tampilan Program Visual Basic untuk Menjalankan Run DEA

9. Berikutnya adalah mengaktifkan solver pada menu references. Lalu klik "ok"

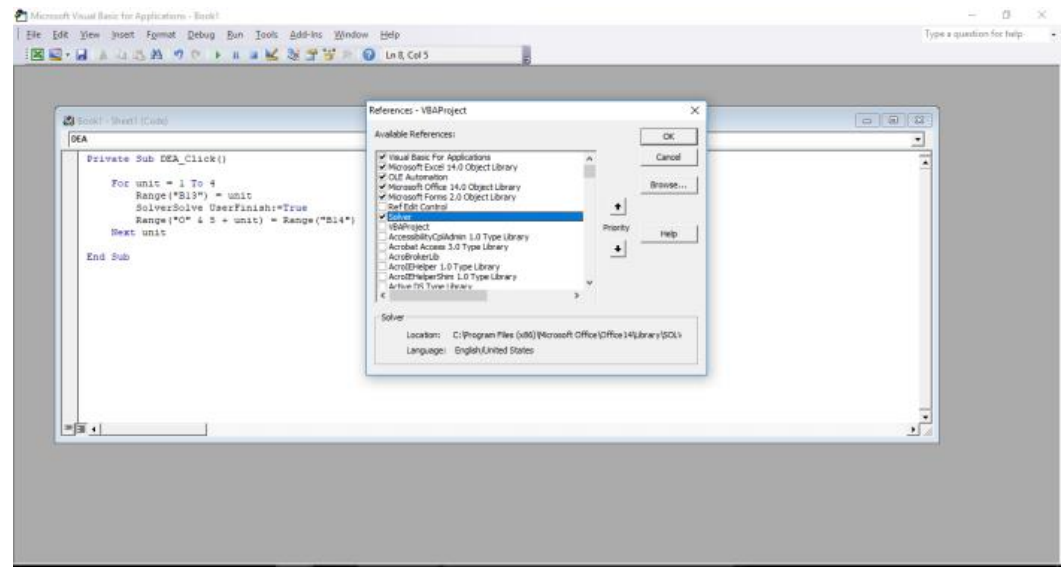

Gambar 9 Tampilan Aktivasi Program Solver Excel

10. Langkah terkahir adalah klik kotak command button, maka muncullah hasil perhitungan efisiensi kineja empat perusahaan

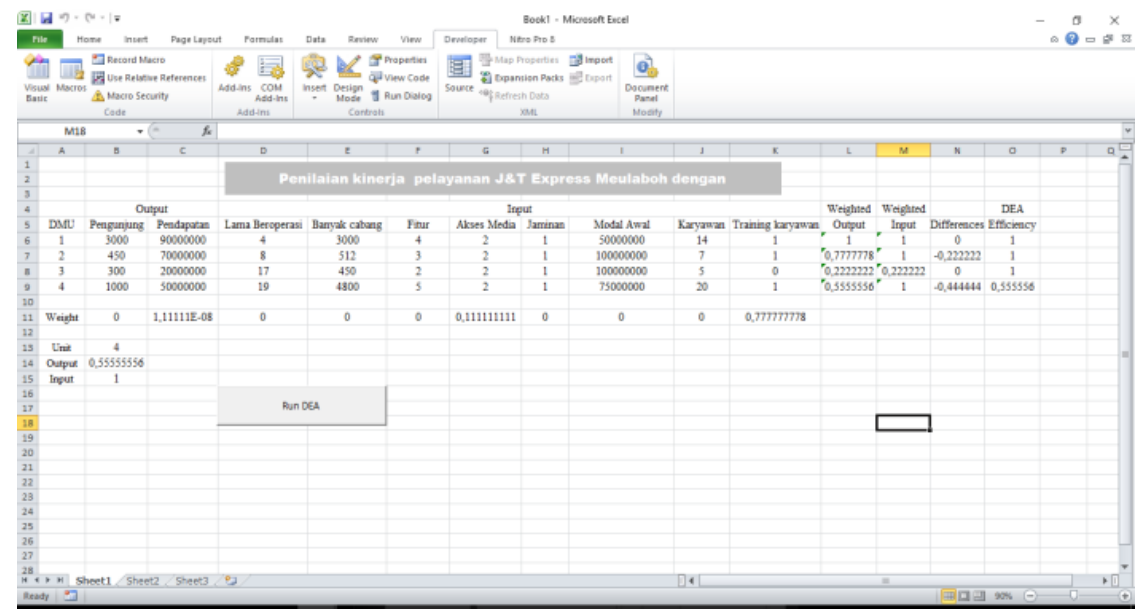

Gambar 10 Tampilan Hasil Nilai Efisiensi Kinerja $D E A$ 
Setelah langkah-langkah dalam solver dilaksanakan, maka didapat bentuk matriks hasil perhitungan, seperti terlihat pada Tabel 6 berikut:

Tabel 6 Matriks Hasil DEA Dengan Menggunakan Solver Pada Microsoft Excel

\begin{tabular}{|c|c|c|c|c|c|c|c|c|}
\hline \multirow[b]{2}{*}{ DMU } & \multicolumn{2}{|c|}{ Output } & \multicolumn{6}{|c|}{ Input } \\
\hline & Pengunjung & Pendapatan & $\begin{array}{c}\text { Lama } \\
\text { Beroperasi }\end{array}$ & $\begin{array}{l}\text { Banyak } \\
\text { cabang }\end{array}$ & Fitur & $\begin{array}{l}\text { Akses } \\
\text { Media }\end{array}$ & Jaminan & Modal Awal \\
\hline 1 & 3000 & 90000000 & 4 & 3000 & 4 & 2 & 1 & 50000000 \\
\hline 2 & 450 & 70000000 & 8 & 512 & 3 & 2 & 1 & 100000000 \\
\hline 3 & 300 & 20000000 & 17 & 450 & 2 & 2 & 1 & 100000000 \\
\hline 4 & 1000 & 50000000 & 19 & 4800 & 5 & 2 & 1 & 75000000 \\
\hline \multicolumn{4}{|c|}{ Input } & \multirow{2}{*}{$\begin{array}{c}\text { Weighted } \\
\text { Output }\end{array}$} & \multirow{2}{*}{$\begin{array}{l}\text { Weighted } \\
\text { Input }\end{array}$} & \multirow{2}{*}{ Differences } & \multirow{2}{*}{\multicolumn{2}{|c|}{$\begin{array}{c}\text { DEA } \\
\text { Efficiency }\end{array}$}} \\
\hline & Karyawan & \multicolumn{2}{|c|}{ Training karyawan } & & & & & \\
\hline & 14 & 1 & & 1 & 1 & \multicolumn{2}{|l|}{0} & 1 \\
\hline & 7 & 1 & & 0,78 & 1 & \multicolumn{2}{|l|}{$-0,22$} & 1 \\
\hline & 5 & 0 & & 0,22 & 0,22 & \multicolumn{2}{|l|}{0} & 1 \\
\hline & 20 & 1 & & 0,56 & 1 & \multicolumn{2}{|l|}{$-0,44$} & 0,56 \\
\hline
\end{tabular}

Matriks pada Tabel 6 menunjukkan bahwa DMU1, DMU2, dan DMU3 menghasilkan nilai efisiensi relatif DEA sebesar 1, maknanya DMU1, DMU2 dan DMU3 sudah cukup baik dan efisien dalam beroperasi. Sedangkan DMU4 hanya menghasilkan nilai efisiensi relatif DEA sebesar 0,56, hal ini menunjukkan bahwa dengan atribut input dan atribut output yang dimiliki oleh DMU4 kurang efisien dalam beroperasi dibandingkan dengan tiga DMU lainnya yang bergerak dalam bidang yang sama.

\section{Kesimpulan}

Hasil pengolahan data menunjukkan bahwa, antar atribut input dan output dari kualitas pelayanan berkorelasi satu dengan yang lain. Dimensi reliability berkaitan dengan atribut lamanya perusahaan berperasi, dimensi responsiveness berkaitan dengan atribut jumlah akses media yang dimiliki oleh perusahaan, dimensi assusrance berkaitan dengan atribut jaminan garansi barang, dimensi emphaty berkaitan dengan atribut ada tidaknya training karyawan perusahaan, dan dimensi tangible berkaitan dengan jumlah cabang setiap perusahaan dan fitur layanan uang dimiliki perusahaan.

Preferensi pelanggan berdasarkan hasil perhitungan diketahui bahwa kualitas pelayanan J\&T Express Meulaboh masih berada di bawah ekspektasi/harapan setiap pelanggan karena seluruh dimensi bernilai negatif. Gap tiap dimensi pelayanan paling buruk secara berurut adalah pada dimensi tangible sebesar -0,68, dimensi assurance sebesar -0,63, dimensi responsiveness sebesar $-0,53$, dimensi emphaty sebesar -0,40, dan dimensi reliability sebesar -0,38.

Pelayanan yang sesuai dengan harapan dan memuaskan pelanggan melalui hasil dari metode servqual yang menunjukkan nilai yang paling mendekati positif dan memiliki gap terkecil yaitu 
pada atribut $\mathrm{P}_{10}$ yang menjelaskan mengenai empati dengan nilai sebesar $-0,22$. Sehingga dalam hal kepedulian pihak J\&T Express Meulaboh sudah hampir mendekati apa yang diinginkan oleh pelanggan.

Kinerja J\&T Express Meulaboh dibandingkan dengan perusahaan/kompetitor sejenis lainnya yang berada di kota Meulaboh sudah beroperasi cukup baik dan efisien karena mendapat nilai efisisensi relatif DEA sebesar 1, tetapi secara kualitas pelayanan belum memenuhi keinginan pelanggan sesuai dengan hasil kesimpulan nomor 2 .

Perbaikan kinerja dari perusahaan J\&T express sebaiknya lebih mengacu kepada perbaikan secara internal. Jal ini dikarenakan ekspektasi pelanggan jauh melebihi kemampuan perusahaan ekspedisi yang ada di Meulaboh. Faktor internal seperti ketepatan layanan (tangible), jaminan kepastian (Assurance) dan respon yang baik terhadap keluhan pelanggan (responsiveness) adalah hal yang perlu diperbaiki secara berkelanjutan oleh perusahaan ekspedisi J\&T Express Meulaboh.

\section{DAFTAR PUSTAKA}

[1] J. E. Panjaitan dan A. L. Yuliati, "Pengaruh Kualitas Pelayanan Terhadap Kepuasan Pelanggan Pada JNE Cabang Bandung [The Influence of Service Quality on Customer Satisfaction at JNE Branch in Bandung]." DeReMa (Development Research of Management): Jurnal Manajemen, vol. 11 no. 2, 2016.

[2] N. Nasyrah, dan D. Darwis, "Analisis Pengaruh Dimensi Kualitas Pelayanan Terhadap Kepuasan Pasien Rawat Inap Di Rumah Sakit Bhayangkara Makassar" Jurnal Mirai Management, vol. 2 no. 1, pp. 133-148, 2017.

[3] N. Nofirza dan K. Indrayani, "Aplikasi metode kano dalam analisis indikator kualitas pelayanan di rumah sakit arifin ahmad pekanbaru” Jurnal Sains, Teknologi dan Industri, vol. 9 no. 1 , pp 1-8, 2011.

[4] F. Li, H. Lu, M. Hou, K. Cui dan M. Darbandi, "Customer satisfaction with bank services: The role of cloud services, security, e-learning and service quality." Technology in Society, vol. 64, pp. 101487, 2020.

[5] M. J. Rezaee, M. Jozmaleki dan M. Valipour, "Integrating dynamic fuzzy C-means, data envelopment analysis and artificial neural network to online prediction performance of companies in stock exchange." Physica A: Statistical Mechanics and its Applications, vol. 489, pp. 78-93, 2018.

[6] F. Tjiptono, "Service Management" Yogyakarta: Andi Offset, 2008.

[7] Nopirin, "Pengantar Ilmu Ekonomi Mikro-Makro" Yogyakarta: BPFE Yogyakarta, 2014.

[8] Yuliani, "Analisis Kualitas Pelayanan Terhadap Kepuasa Pelanggan Dengan Menggunakan Metode Servqual Di SPBU Pasti PAS Meurebo Kabupaten Aceh Barat", Skripsi Jurusan Teknik Industri, Universitas Teuku Umar: Meulaboh. 2016.

[9] Sugiyono, "Metode Penelitian Kuantitatif, Kualitatif, dan R\&D" Bandung: Alfabeta, 2010.

[10] S. Azwar, "Reliabilitas dan Validitas" edisi 4, Yogyakarta: Pustaka Pelajar, 2014.

[11] F. Tjiptono dan G. Chandra, "Service, Quality, \& Satisfaction" Edisi 3. Yogyakarta: Andi Offset, 2011. 